scientists from 33 countries, but the list of participants does not include the names of a number of world figures who certainly were present at the meetings.

Apart from the inaugural and presidential addresses, 27 papers are printed; most were presented by their authors and followed by a discussion which is given in summary form. The papers are arranged in four groups: the state of scientific knowledge, nomadism, alternative uses of scarce water supplies and, finally, four papers on public awareness of the educational problem. The thirteen papers in the general section deal with water, ground-water, climatology, microclimatology, soils, salinification, plant physiology and ecology, human ecology, insects, winds and solar energy and saline water conversion. It is interesting to find nomadism objectively studied by the Food and Agriculture Organization and viewed as a proper use of semi-arid lands under adequate control - thus extending on a world-wide basis the famous Cain and Abel experiment of Israel.

It would be invidious to select papers from this rich collection for individual comment; but three conclusions would seem to emerge. The first is that the research needed is usually in the borderland between present-day accepted fields of knowledge, in fact, the interrelation of the many factors. The second is the delicate balance, easily upset, which exists in arid lands between the biota, including man, and the environment. The third is the need for an open mind, willing constantly to re-think and reassess the problems and their solution.

L. Dudley Stamp

\title{
DAIRY RESEARCH IN SCOTLAND
}

T HE Hannah Dairy Research Institute at Ayr now has a staff of about ninety, of whom some thirty are qualified in agriculture or science. The recent triennial report* shows that the entire process of dairying is being covered, from the production of food on the farm to the chemistry, biochemistry and bacteriology of milk and milk products. The programme of research is agreed in consultation with the Agricultural Research Council (London) and the Department of Agriculture for Scotland.

The previous report described a unique range of new equipment for respiration experiments with sheep and cattle, and a splendid new climatic laboratory. It is evident that these have been put to immediate use and that the work in these fields is wisely receiving emphasis. Thus the careful reader will find on p. 33 further support for the conclusion that while rations differing considerably in composition may be equally valuable for satisfying the maintenance requirements of ruminants, their nutritive value for production may differ widely. Much vital supporting information is now being assembled,

* Hannah Dairy Research Institute. Report for the three years ended 31st March, 1962. on such questions as the effect of environment, movement and lactation on the energy requirements of sheep and cattle. The eventual effect of this work may well be felt wherever feeding standards are used.

Capital for the climatic laboratory was provided by the Colonial Office in order to obtain basic know. ledge of value in the improvement of cattle in hot countries. A broad and vigorous approach is being made to the study of factors that influence tempera. ture regulation, heat tolerance and acclimatization. Much of this may be of value also in temperate countries.

This Institute is clearly making a major contribution to research on many aspects of Britain's greatest and most vital agricultural enterprise. It may be symptomatic of the times, but it will nevertheless be surprising in some other countries that less than 1 per cent of the money required annually should now come from voluntary contributions.

Sufficient background is provided to enable the general reader to appreciate the reason for doing each piece of work. While a great deal of factual information is included, ample references are given to enable the specialist to trace detailed reports. As always, this report is impeccably edited.

\section{UPTAKE OF GLUCOSE, AMINO-ACIDS AND VITAMINS BY HUMAN AMNION CELL CULTURES INFECTED WITH A TICK-BORNE ENCEPHALITIS VIRUS}

\author{
By Dr. P. HALONEN, L. HJERP, M. PYHTILÄ and P. WECKSTRÖM
}

Department of Virology, University of Helsinki, and Microbiological Laboratory, Lääketehdas Orion Oy, Helsinki

\begin{abstract}
CHEMICALLY defined media designed primarily i for cell cultures are extensively used for the propagation of viruses in such cultures. To obtain the maximal yield of viruses requiring a lengthy incubation and maturation time in cell cultures, change of the medium must usually be omitted. Accordingly, the best medium for such virus propagation may not necessarily be of the same composition as that for optimal cell growth, when frequent change of the medium is possible. To examine the basic aspects of this problem it appeared important to
\end{abstract}

know whether a critical loss of metabolites from a chemically defined medium could be obtained during prolonged incubation of uninfected and virusinfected cell cultures. This communication describes the changes in the concentrations of glucose, aminoacids and vitamins of the B-group in Eagle's minimum essential medium ${ }^{1}$ in uninfected human amnion cell cultures and in cultures infected with a tickborne encephalitis virus.

Strain $A 52$ of the tick-borne encephalitis virus was selected because in the continuous line of human 